\title{
Atomoxetine treatment may decrease striatal dopaminergic transporter availability after 8 weeks: pilot SPECT report of three cases
}

This article was published in the following Dove Press journal:

Neuropsychiatric Disease and Treatment

19 November 2015

Number of times this article has been viewed

\author{
Aynur Pekcanlar Akay' \\ Gamze Capa Kaya ${ }^{2,3}$ \\ Burak Baykara' \\ Yusuf Demir ${ }^{2,3}$ \\ Handan Özek' \\ Sevay Alsen' \\ Mine Sencan Eren ${ }^{2,3}$ \\ Neslihan Inal Emiroglu' \\ Turkan Ertay ${ }^{2,3}$ \\ Yesim Ozturk ${ }^{4}$ \\ Suha Miral' \\ Hatice Durak ${ }^{2,3}$ \\ Evren Tufan ${ }^{4}$ \\ 'Department of Child and Adolescent \\ Psychiatry, ${ }^{2}$ Department of Nuclear \\ Medicine, ${ }^{3}$ Department of Pediatrics, \\ Dokuz Eylul University Medical \\ Faculty, Izmir, ${ }^{4}$ Department of Child \\ and Adolescent Psychiatry, Abant İzzet \\ Baysal University, Bolu, Turkey
}

\begin{abstract}
Attention deficit/hyperactivity disorder is one of the most common neurodevelopmental disorders. The pathophysiology is thought to involve noradrenaline and dopamine. The role of dopamine transporter (DAT) was evaluated in imaging studies using mostly dopamine reuptake inhibitors. Atomoxetine is a selective noradrenaline reuptake inhibitor. Here we report the results of a pilot study conducted to evaluate changes in striatal DAT after 8 weeks of atomoxetine treatment. Our results suggest that 8 weeks of atomoxetine treatment may change striatal DAT bioavailability as measured via SPECT but that change was not correlated with genotype or clinical improvement.
\end{abstract}

Keywords: neuroimaging, dopamine, noradrenaline, SLC6A3 protein, human, pragmatic clinical trial, pilot study

\section{Introduction}

Catecholaminergic neuro-transmission, especially involving dopamine (DA) and noradrenaline (NA), is thought to be mostly responsible for the pathogenesis of attention deficit/hyperactivity disorder (ADHD). ${ }^{1}$ The contribution of presynaptical dopamine transporter (DAT) has been suggested by imaging studies that evaluated the efficacy of treatment with DA reuptake inhibitors such as methylphenidate. ${ }^{2}$ Atomoxetine, a selective inhibitor of the presynaptic noradrenaline transporter, with a very low affinity for DAT is a nonstimulant approved for the treatment of ADHD. ${ }^{3}$ Because noradrenaline transporter is primarily responsible for the clearance of DA in prefrontal cortex, atomoxetine treatment increases both extracellular NA and DA in the prefrontal cortex, but NA in other regions. ${ }^{4}$ Although the effects of atomoxetine on striatal DAT function in rodents have been studied previously, data on patients is scarce. ${ }^{5}$ Here, we report post-treatment changes in Tc-99m TRODAT-1 brain SPECT of three adolescents (one of whom was female aged 158 months with ADHD inattentive type; two were male aged 167 and 175 months with ADHD combined type) who received atomoxetine treatment for 8 weeks.

\section{Patients and methods}

The patients were selected from adolescent (12-17 years old) patients with suspected ADHD who applied to the Child and Adolescent Psychiatry Outpatient Department of Dokuz Eylul University Medical Faculty between December 2013 and February 2014. The patients had to be treatment naïve and free of medical, neurological, and psychiatric comorbidities. All prospective patients and parents were informed of the study procedures
Department of Child and Adolescent Psychiatry, Abant İzzet Baysal University, Golkoy, 14280 Bolu, Turkey

Tel +905325269416

Email tevrenus@yahoo.com 
Table I Genotypes and atomoxetine dosages of patients in a pilot study to evaluate the effect of atomoxetine on striatal DAT availability

\begin{tabular}{llll}
\hline & Patient I & Patient 2 & Patient 3 \\
\hline Baseline & & & \\
DAT & $10 / 9$ & 10 & 10 \\
DRD4 & $4 / 3$ & 4 & $7 / 4$ \\
COMT & $\mathrm{G} / \mathrm{G}$ & $\mathrm{G} / \mathrm{G}$ & $\mathrm{G} / \mathrm{A}$ \\
$\quad$ Atomoxetine (mg/day) & 25 & 36 & 36 \\
End & & & \\
$\quad$ Atomoxetine (mg/day) & 60 & 100 & 85 \\
\hline
\end{tabular}

Abbreviations: DAT, dopamine transporter; DRD4, dopamine receptor type 4; COMT, catechol-O-methlytransferase.

and only patients providing written assent whose parents provided written informed consent were included in the study. The study was approved by the Institutional Review Board of Dokuz Eylul University and all study procedures were in accordance with the Declarations of Helsinki and local laws and regulations. ADHD diagnoses were made based on DSMIV-TR criteria via Turkish version of the Kiddie-Schedule for Affective Disorders and Schizophrenia-Present and Lifetime version, which was found to be valid and reliable previously. ${ }^{6}$ All patients were right handed and treatment-naïve with an IQ level $>80$ (confirmed with Turkish version of Wechsler Intelligence Scale for Children-Revised). ${ }^{7}$ Genotypes and atomoxetine doses of patients are listed in Table 1.

Mean CGI-ADHD-severity for all patients was five (significantly impaired) at visit 1. Baseline Du Paul ADHD
Questionnaire total scores were 28, 28, and 20, respectively. Neurological examinations, magnetic resonance imagings, and electrocardiograms were normal. After the baseline SPECT, each subject's dose was individually titrated in accordance with the clinical response. Starting dose was $0.5 \mathrm{mg} / \mathrm{kg}$ titrated within 4 weeks up to $1.6 \mathrm{mg} / \mathrm{kg}$. The patients were seen weekly at the dose adjustment phase, and then monthly. Height, weight, pulse, blood pressure, side effects, Du Paul ADHD Questionnaire, and CGI-ADHDseverity scale were assessed at visits.

Tc-99m TRODAT-1 was obtained by the Institute of Nuclear Energy Research (Taipei, Taiwan). SPECT was performed at the baseline and at the 8 th week (under treatment). Radiochemical purity of Tc-99m TRODAT-1 was exceeded $95 \%$ when tested by high-performance liquid chromatography. Three hours after the injection of 444-814 MBq Tc-99m TRODAT-1, brain images were obtained using a gamma camera (Philips Forte A-Z Gamma Camera, Holland, the Netherlands). The range of activities for the tracer varied due to differing body weights of patients (range $=38.5-73.0 \mathrm{~kg}$ ). A total of 128 frames were acquired in $128 \times 128$ matrices, $30 \mathrm{~s} /$ frame, $1.46 \mathrm{zoom}$, and $360^{\circ}$. Transaxial slices were transformed into plane images. Regions of interest were drawn on the right and left basal ganglia and the localization of cerebellum as the background. The two consecutive transverse slices showing the highest uptake in the basal ganglia were selected. Mean counts per pixel were used. Mean corrected activity in the
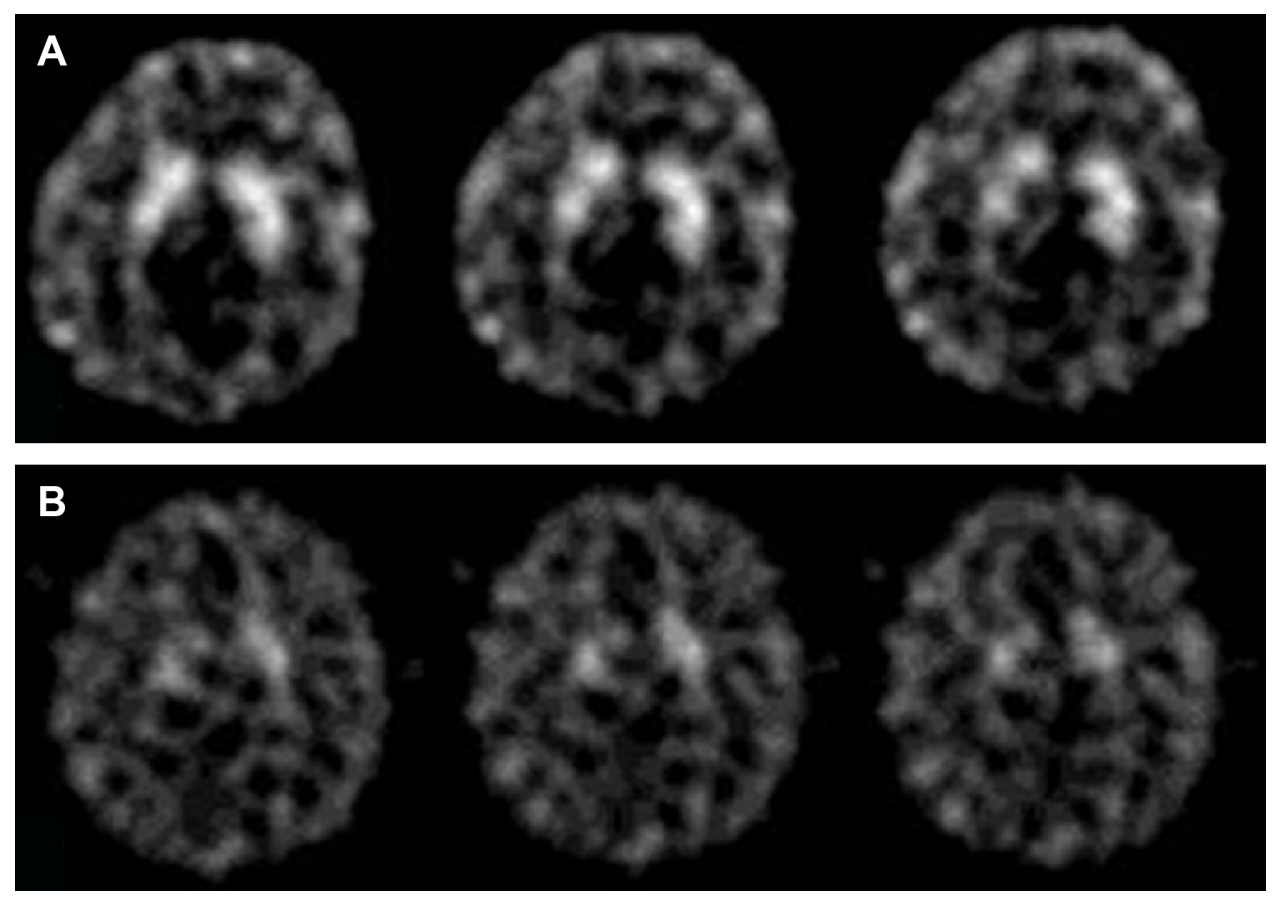

Figure I Tc-99m TRODAT-I SPECT image of one of the patients before (A) and after (B) treatment with atomoxetine. 
basal ganglia was calculated as follows: (basal gangliabackground)/background. The images were evaluated visually and semi-quantitatively as above the scalp activity, equivalent to scalp activity, and below the scalp activity by involvements observed in the basal ganglion. Wilcoxon signed-rank test and Spearman's rank order correlation were used in analyses. $P$-value was set at 0.01 .

\section{Results and conclusion}

In the visual, semi-quantitative analysis (Figure 1), there was a decrease in baseline availability of DAT after 8 weeks of atomoxetine treatment in both right and left basal ganglia (pre $=1.09 \pm 0.96$ and post $=0.97 \pm 0.11$ for left basal ganglia, pre $=1.05 \pm 0.13$ and post $=0.86 \pm 0.14$ for right basal ganglia, $P<0.01)$. Du Paul Total scores at end point were 18,12 , and 17 , respectively. The effects of dopamine transporter 1 , dopamine receptor type 4 and catechol-Omethlytransferase were explored with separate analyses, which were all nonsignificant (Wilcoxon signed-rank test, $P>0.01)$. An exploratory analysis of correlation between CGI-S scores and DAT availability was not significant (Spearman's rank order test, $P>0.01$ ).

To conclude, in this pilot study, we observed that 8 weeks of treatment with atomoxetine may change DAT bioavailability as evaluated via Tc-99m-TRODAT-1, however, this change may not be affected by the genotype of patients and did not correlate with clinical improvement. These observations should be interpreted as exploratory and hypothesis generating, rather than conclusions.

Previously, it was reported that DAT binding was higher in adults with ADHD and the reduction in DAT binding with methylphenidate treatment correlated with clinical improvement. ${ }^{8}$ Also, genotype of patients was reported to affect the magnitude of DAT reduction in patients with ADHD receiving treatment. ${ }^{9}$ The discrepancy between our results and those reported previously may be due to differing age ranges, treatments, and imaging characteristics of the patients.

The sample size of this pilot trial was too small, and there was no control group to compare a placebo effect. Heterogeneous subtypes of ADHD and sexes may also be limitations and our finding may also be an artifact. We believe the probable effect of atomoxetine on DAT availability should be evaluated with further studies.

\section{Acknowledgments}

This study is partially supported by Dokuz Eylul University Research Committee, Fogarty MH/DD program, and the Institute of Nuclear Energy Research (INER, Taipei, Taiwan).

\section{Author contributions}

All authors made substantial contributions to conception and design, acquisition of data, or analysis and interpretation of data; took part in either drafting the article or revising it critically for important intellectual content; and gave final approval of the version to be published.

\section{Disclosure}

APA is a member of the Advisory Board of Janssen and Lilly Pharmaceutical Companies, all other authors have no conflicts of interest to disclose.

\section{References}

1. Faraone SV, Perlis RH, Doyle AE, et al. Molecular genetics of attentiondeficit/hyperactivity disorder. Biol Psychiatry. 2005;57:1313-1323.

2. La Fougère C, Krause J, Krause KH, et al. Value of 99mTc-TRODAT-1 SPECT to predict clinical response to methylphenidate treatment in adults with attention deficit hyperactivity disorder. Nucl Med Commun. 2006;27(9):733-737.

3. Heal DJ, Smith SL, Kulkarni RS, Rowley HL. New perspectives from microdialysis studies in freely-moving, spontaneously hypertensive rats on the pharmacology of drugs for the treatment of ADHD. Pharmacol Biochem Behav. 2008;90:184-197.

4. Arnsten AF. Toward a new understanding of attention-deficit/ hyperactivity disorder pathophysiology: an important role for prefrontal cortex dysfunction. CNS Drugs. 2009;23(Suppl 1):33-41.

5. Del'Guidice T, Lemasson M, Etiévant A, et al. Dissociations between cognitive and motor effects of psychostimulants and atomoxetine in hyperactive DAT-KO mice. Psychopharmacology (Berl). 2014;231(1): 109-122.

6. Gokler B, Unal F, Pehlivanturk B, Cengel Kultur E, Akdemir D, Taner Y. Okul Çağı Çocukları için Duygulanım Bozuklukları ve Şizofreni Görüşme Çizelgesi-Şimdi ve Yaşam boyu Şekli-Türkçe Uyarlamasının Geçerlik ve Güvenirliği. [Reliability and validity of schedule for affective disorders and schizophrenia for school age children-present and lifetime version - Turkish version (K-SADS-PL-T)]. Turkish J Child Adolesc Psychiatry. 2004;11:109-116.

7. Savasir I, Sahin N. Wechsler Çocuklar İçin Zeka Ölçeği-Gözden Geçirilmiş Formu Elkitabi. [Manual for the Wechsler Intelligence Scale for Children - Revised (WISC-R)]. Ankara: Turkish Pscyhology Association Publications; 1995.

8. Dresel S, Krause J, Krause KH, et al. Attention deficit hyperactivity disorder: binding of [99mTc]TRODAT-1 to the dopamine transporter before and after methylphenidate treatment. Eur J Nucl Med. 2000;27(10): $1518-1524$.

9. Szobot CM, Roman T, Hutz MH, et al. Molecular imaging genetics of methylphenidate response in ADHD and substance use comorbidity. Synapse. 2011;65(2):154-159. 


\section{Publish your work in this journal}

Neuropsychiatric Disease and Treatment is an international, peerreviewed journal of clinical therapeutics and pharmacology focusing on concise rapid reporting of clinical or pre-clinical studies on a range of neuropsychiatric and neurological disorders. This journal is indexed on PubMed Central, the 'PsycINFO' database and CAS,

and is the official journal of The International Neuropsychiatric Association (INA). The manuscript management system is completely online and includes a very quick and fair peer-review system, which is all easy to use. Visit http://www.dovepress.com/testimonials.php to read real quotes from published authors.

Submit your manuscript here: http://www.dovepress.com/neuropsychiatric-disease-and-treatment-journal 